\begin{tabular}{|c|c|c|}
\hline 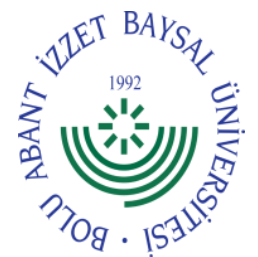 & $\begin{array}{l}\text { International Journal of Agriculture and Wildlife } \\
\qquad \text { Science } \\
\text { http://dergipark.org.tr/jiaws }\end{array}$ & 每 \\
\hline
\end{tabular}

Research Article

\title{
Effects of Solid and Liquid Vermicompost Application on Bean Growth and Common Bacterial Blight Disease in Different Growth Medium
}

\author{
Yusuf Öztürkci $^{1^{*}}$ (D)， Ahmet Akköprü² \\ ${ }^{1}$ Agriculture and Rural Development Support Institution Van Province Coordination Unit. Van, Turkey \\ 2Plant Protection Department, Faculty of Agriculture, Van Yüzüncü Yıl University. Campus, 65080, Van, Turkey
}

Received: 02.09.2020 Accepted: 06.10.2021

\section{Keywords:}

Vermicompost, common bean, Xanthomonas axonopodis pv. phaseoli, biological control

*Corresponding author ahmetakkopru@yyu.edu.tr
Abstract. In this study, the effect of solid and liquid forms of vermicompost on plant growth and bacterial common blight disease in different growth media were investigated. Vermicompost was applied at the rate of 1/100,1/150,1/200 in liquid form and vermicompost in solid form at the rate of $10 \%, 20 \%, 40 \%$ to peat and soil growing medium. The pathogen, Xanthomonas axonopodis pv. phaseoli

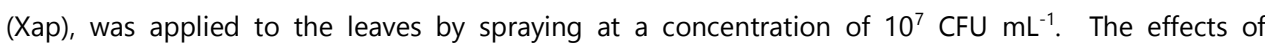
applications on plant growth parameters, total chlorophyll content, and disease severity were evaluated. It was determined that the effects of the applications varied according to vermicompost form and growth medium. Liquid vermicompost applications displayed more positive effects on root growth in the soil growing medium. However, the application of liquid vermicompost did not affect disease severity. It was observed that the $40 \%$ dose of vermicompost in solid form inhibited plant growth and caused chlorosis in both growth media. However, 10 and $20 \%$ of doses had no adverse effects on plant growth. Also, the application of $10 \%$ solid vermicompost to peat growing medium reduced the disease development by $48 \%$. In soil growth medium, application doses of $10 \%$ and $20 \%$ prevented disease development by $62 \%$ and $54 \%$.

\section{Katı ve Sıvı Solucan Gübresi Uygulamalarının Farklı Yetişme Ortamlarında Fasulye Gelişimine ve Bakteriyel Adi Yaprak Yanıklığı Hastalığına Etkileri}

\section{Anahtar kelimeler:}

Vermikompost, fasulye, Xanthomonas axanopodis pv. phaseoli, biyolojik kontrol
Özet. Bu çalışmada, katı ve sıvı formlardaki Vermilkompostun farklı yetiştirme ortamlarında bitki büyümesi ve bakteriyel adi yaprak yanıklığı hastalığına etkisi araştırılmıştır. Vermilkompostun sıvı formu $1 / 100,1 / 150,1 / 200$ oranlarında, katı formu ise $\% 10, \% 20, \% 40$ oranlarında torf ve toprak yetiştirme ortamına uygulanmıştır. Fasulye yaprak patojeni, Xanthomonas axonopodis pv. phaseoli (Xap), $10^{7} \mathrm{CFU} \mathrm{mL} \mathrm{mL}^{-1}$ konsantrasyonda yapraklara püskürtülerek uygulanmıştır. Uygulamaların bitki büyüme parametrelerine, toplam klorofil içeriğine ve hastalık şiddetine etkileri değerlendirilmiştir. Genel olarak uygulamaların bitki gelişimi ve hastalık şiddetine etkileri vermikompost formuna ve yetiştirme ortamına göre değiştiği belirlenmiştir. Sıvı vermikompost, toprak yetiştirme ortamında kök gelişimi üzerinde daha olumlu etkiler göstermiştir. Bununla birlikte, sıvı vermikompost hastalık şiddetini etkilememiştir. Katı vermikompostun \%40'lık dozunun bitki büyümesini engellediği ve her iki büyüme ortamında kloroza neden olduğu belirlenmiştir. Bununla birlikte, \%10 ve \%20'lik dozların bitki büyümesi üzerinde hiçbir olumsuz etkisi gözlenmemiştir. Ayrıca, torf yetiştirme ortamına \%10 katı vermikompost uygulanması hastalık gelişimini \%48 oranında azaltmıştır. Toprak ortamında ise \%10'luk katı formdaki vermikompost \%62, \%20 dozunda ise \%54 oranında hastalık gelişimini önlemiştir. 


\section{INTRODUCTION}

The concept of vermiculture, which started in the second half of the twentieth century and started industrial production in the 1980s; is defined as the process of ripening organic wastes via earthworm (Saday, 2013). Vermicompost, is obtained by consumption of fermented waste by earth worms such as Eisenia spp., Perionyx excavates, Dendrobaena veneta and Lumbricus rubellusin earthworms (Dominguez and Edwards, 2011). Factors such as high content of organic matter and plant nutrients which are almost fully absorbable, increase in beneficial microbial activity and improvement in physical structure of soil give vermicompost a unique place in agricultural production (Bellitürk and Görres, 2012). Vermicompost may contribute to germination, rooting, growth and early ripening of the plant. Also, benefits such as support to sustainable waste management, absence of production waste, potential to reduced utilization of chemical pesticides and fertilizers make it an economic and environmentally friendly production input in agricultural production (Edwards et al., 2010; Vanlı and Bedük, 2013).

The common bean is widely produced all over the world and consumed in different forms as an important economic product. However, beans are subject to many diseases and pest attacks which account for significant crop losses (Graham and Ranalli, 1997; Singh and Schwartz, 2010). One of the most important disease is common bacterial blight disease caused by Xanthomonas axonopodis pv. phaseoli (Xap). The pathogen can be observed in all bean producing continents and causes significant yield losses (CABI, 2019). Xap effects leaves, shoots, pods, and seeds. The agent is seedborne and can enter the plant through natural openings and wounds. The bacterial agent that settles under the seed coat can remain alive for many years (EPPO, 2006; CABI, 2019). In intensive infections, the disease can cause up to $40 \%$ yield loss (Singh and Miklas, 2015). Despite some methods have been proposed to control the disease, the most commonly used approach is chemical control with pesticides. Against the relative success achieved by the pesticide, intensive use of chemicals has led to negative effects on environmental health, it also causes pathogens to develop resistance to these chemicals (Vidaver, 2002; Bruce, 2010; Griffin et al., 2017). On the other hand, organic inputs promoting contribute to plant health and development are gaining increasing interest. In this context; vermicompost and vermicompost extracts have an important potential to contribute to yield and plant health.

Vermicompost and its extracts can contribute to plant growth in many ways. Though this contribution can be at different levels depending on soil structure, plant type and species, vermicompost raw material and formation process and the application dose and type (Franke-Whittle et al., 2019). In general, vermicompost may enhance plant development; i) by providing micro and macro nutrients and facilitating their absorption ii) by increasing the concentration of humic acid in the soil, iii) by supplying plant hormones, iv) by increasing soil porosity and moisture retention capacity, v) by changing soil mass density and $\mathrm{pH}$ vi) increasing microbial activity (Sarma et al., 2010; Simsek-Ersahin, 2011; Datta et al., 2016).

The vermicompost in different forms, has the potential to be used against diseases and pests in addition to its contributions to plant growth and yield. Studies conducted with vermicompost products have generally focused on soil-borne diseases or root pathogens. In vitro studies have shown that the effect levels of vermicompost extracts against fungal and bacterial plant pathogens vary according to microorganisms (Tutar, 2013). In addition, in vivo studies with vermicompost show significant inhibition of diseases caused by pathogens such as: Pythium solani and Verticillium sp. (Chaoui et al., 2002; Edwards and Arancon, 2004), Rhizoctonia solani, Fusarium spp.(Chaoui et al., 2002), Sclerotium rolfsii (Sahni et al., 2008), Erwinia chrysanthemi (Kharayat and Singh, 2016) Ralstonia solanacearum (Singh et al., 2017).

Edwards and Arancon (2004) and Simsek-Ersahin (2011) stated that the effect of vermicompost applications to inhibit plant diseases is biological, rather than chemical. Disease inhibition mechanisms of vermicomposts are defined in two types as "general and specific" (Edwards and Arancon, 2004; Simsek-Ersahin, 2011). It is reported that General inhibition occurs by activation of one or more mechanisms such as; competition, antibiosis, hyperparasitism and stimulated plant resistance (Sarma et al., 2010; Simsek-Ersahin, 2011; Datta et al., 2016). The second type of disease inhibition mechanism is the "specific suppression", by which a narrow pathogen group or a pathogen is suppressed (Edwards and Arancon, 2004; Simsek-Ersahin, 2011). Increased microbial activity and diversity in soil is an important factor in both mechanisms (Sarma et al., 2010; Simsek-Ersahin, 2011; Datta et al., 2016). Furthermore, the most important factor that distinguishes vermicompost from other composts is solomic fluid. Wang et al. (2006) stated that during the formation process of vermicompost, solomic fluid within the digestive systems of the worms mixes with the manure and imbues it with anti-microbial properties.

In this scope, studies on the control of bacterial leaf pathogens the application of different vermicompost forms to the different growing medium and on plant growth are very limited. In this study, the effects of vermicompost of solid and liquid forms on plant growth parameters and against common bacterial blight disease 
Öztürkci and Akköprü, Effects of Solid and Liquid Vermicompost Application on Bean Growth and Common Bacterial Blight Disease in Different Growth Medium

caused by the leaf pathogen Xanthomonas axonopodis pv. phaseoli (Xap) on common bean at different growth medium (soil and peat) were investigated.

\section{MATERIAL AND METHOD}

\section{Vermicompost Preperation}

Vermicompost was used in two different forms as solid vermicompost (VC) and liquid vermicompost (VS). The general characteristics of vermicomposts are given in table 1.

Solid vermicompost (VC): The worm food prepared for the production of solid vermicompost consists of a mix of $85-90 \%$ cow dung which passed through manure separator and $10-15 \%$ of household and garden waste (tea pulp, fruit and vegetable wastes). Eisenia fetida worms, which were left in $80 * 120 \mathrm{~cm}$ size plastic crates with grids at the bottom, were fed periodically with the food. The worms in plastic crates incubated at $18-240 \mathrm{C}$. The feeding was made once per week, for 8-10 thousand worms per square meter with a height of 5-7 cm. As a result of the weekly feeding, the food that the worms turned into fertilizer reached a height of approximately one meter within 4 months. In order to separate worms from the fertilizer, small crates with fresh food used to lure them. For the purpose of moisture reduction, the fertilizer was taken out of plastic crates and laid on covered concrete floor with air circulation and reversed weekly. After three months of moisture reduction and rest, solid worm fertilizer (vermicompost - VC) moisture level was lowered aproximately to 20-30\% (It was dried up to level that could be sieved) (Edwards, 2004). Subsequently is was sieved to be made ready for use.

Liquid vermicompost (VS): The other form of worm fertilizer used in the study, is a commercial preparation obtained from the same worm species (Eisenia fetida) (Cansuyu Organic Liquid Worm,Turkey) (Table 1)

VC was applied to the growing media by mixing $10 \%, 20 \%$ and $40 \%(\mathrm{w} / \mathrm{w})$ in three different ratios (Edwards and Arancon, 2004). VS was again prepared in three different doses by diluting $1 / 100$ (recommended dose by producer), $1 / 150$ and $1 / 200$ ( $v / v$ ) with water. Prepared VS suspensions were applied twice as $20 \mathrm{ml}$ plant-1 by drenching method after seed sowing and 24 hours before pathogen inoculation (Table 2).

Table 1. Solid vermicompost (VC) and liquid vermicompost (VS) properties used in the study. Çizelge 1. Çalışmada kullanılan Katı vermikompost (VC) ve sıvı vermikompostun (VS) özellikleri.

\begin{tabular}{|c|c|c|}
\hline Content & VS & VC \\
\hline Total organic matter & $\% 58$ & $\% 52.3$ \\
\hline Total Nitrogen & $\% 0.82$ & $\% 4.1$ \\
\hline Total Humic and Fulvic Acid & $\% 35.67$ & $\% 46.1$ \\
\hline Water soluble Potassium oxide & 3.63 & 2.9 \\
\hline Total Phosphor Pentaoxide (P2O5) & - & $\% 2.1$ \\
\hline Microbial density (CFU mL ${ }^{-1}$ ) & $8.6 \times 107$ & - \\
\hline $\mathrm{pH}$ & 9.02 & 8.1 \\
\hline
\end{tabular}

\section{Pot Experimental Design}

Seeds of common bean (Phaseolus vulgaris cv. Gina) were planted in $300 \mathrm{ml}$ plastic pots filled with two different growth medium which consists of sterile peat, and soil/perlite/animal manure (1/1/1) mix. The pots were kept in the climate chamber at $24{ }^{\circ} \mathrm{C}$ for plant growth (16 hours of light and about $50 \%$ humidity): Hoagland nutrient solution was regularly applied for the nutrient needs of bean seedlings grown in peat.

\section{Pathogen Inoculation and Disease Suppression Analysis}

The pathogen, Xanthomonas axonopodis pv. phaseoli (Xap), isolated from common bean in Antalya, Turkey, was provided by Prof Dr Hüseyin Basım (Faculty of Agriculture, Akdeniz University, Antalya, Turkey). When the bean seedlings were at a three-leaf stage, the pathogen was inoculated by spraying. For this purpose, Xap grown on TSA medium ( $1.7 \mathrm{~g} \mathrm{~L}^{-1}$ tryptone, $0.3 \mathrm{~g} \mathrm{~L}^{-1}$ soybean peptone, $0.25 \mathrm{~g} \mathrm{~L}^{-1}$ glucose, $0.5 \mathrm{~g} \mathrm{~L}^{-1} \mathrm{NaCl}, 0.5 \mathrm{~g} \mathrm{~L}^{-1} \mathrm{~K}^{\mathrm{HHPO}} 4$ and $15 \mathrm{~g} \mathrm{~L}^{-1}$ agar) at $28^{\circ} \mathrm{C}$ for $48 \mathrm{~h}$ was inoculated. Xap suspension was prepared from this fresh culture at density

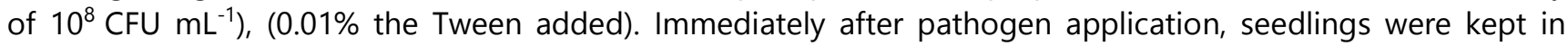
polyethylene cabins for 48 hours in the climate chamber (kept in the dark for the first 24 hours) in order to generate high humidity for pathogen development

On the 21st day after pathogen application, disease symptoms is scored according to scale 1-5 (1: No symptoms, 2: $1-5 \%$ of the leaf necrosis or individual spots, 3: $6-25 \%$ of the leaf symptoms and necrosis, $4: 26 \%$ of the leaf symptoms and necrosis in -50; 5: symptoms and necrosis in 50\% of the leaf or death of the leaf) (Akköprü, 2020). Disease severity was calculated using the formula below based on score values. The efficacy of the treatment was calculated as compared to the pathogen-alone treatment. 


$$
\text { Disease index }=\frac{\left.\sum \text { (Rating number } x \text { Number of leaves in the rating }\right)}{\text { Total number of leaves } x \text { Highest rating }} \times 100
$$

\section{Determination of Plant Growth Parameters}

At the end of the experiments, the number of leaves of the plants was determined by counting all leaves except cotyledon and bifoliate leaves. Leaf chlorophyll content was determined by using chlorophyll meter (Konica Minolta SPAD-502 Plus) on the last day of the experiment. The plants were uprooted and cut from the root collar. Roots were washed with tap water to remove residues of the growing medium. The water on the roots and stems were removed with the help of drying papers to determine the fresh root and stem weight. Afterwards, both plant parts were dried in a drying-oven at $65^{\circ} \mathrm{C} 72 \mathrm{~h}$ and then weighed.

\section{Data Analysis}

Experiments including treatments were set up according to completely randomised with ten replicates. In all experiments, at least, 10 seedlings were used in each group. Data obtained in climate chamber studies were analysed using SPSS v17.0 statistical software. Significant differences between treatments were determined using Duncan's multiple range test with a significance level of $P \leq 0.05$.

Table 2. Vermicompost application doses in soil and peat growing medium and working groups formed with Xap. Çizelge 2. Toprak ve Torf yetiştirme ortamında vermikompost) uygulama dozları ve Xap ile oluşturulan çalışma gurupları.

\begin{tabular}{ll}
\hline NC (- Xap) & PC (+Xap) \\
VC $\% 10$ & VS $1 / 100$ \\
VC $\% 20$ & VS $1 / 150$ \\
VC $\% 40$ & VS $1 / 200$ \\
VC $\% 10+$ Xap & VS $1 / 100+$ Xap \\
VC $\% 20+$ Xap & VS $1 / 150+$ Xap \\
VC $\% 40+$ Xap & VS $1 / 200+$ Xap \\
\hline
\end{tabular}

* Xap: Xanthomonas axonopodis pv. phaseoli NC: (negative control), PC: only Xap application, VC: Solid vermicompost, VS; liquid vermicompost.

\section{RESULTS}

\section{Disease Suppression}

It was determined that the effect of vermicompost applications on disease severity varies based on to growth medium, application form and dosage. The most successful application in terms of suppressing the disease in peat growth medium was VC $10 \%$ which was observed to be $48 \%$ efficient. This effect was found to be statistically significant. Although other doses of VC administration caused decreases in disease severity by up to $31 \%$, this effect was not found to be statistically significant. VS applications did not have a significant effect on disease formation in peat growth medium. (Fig. 1).

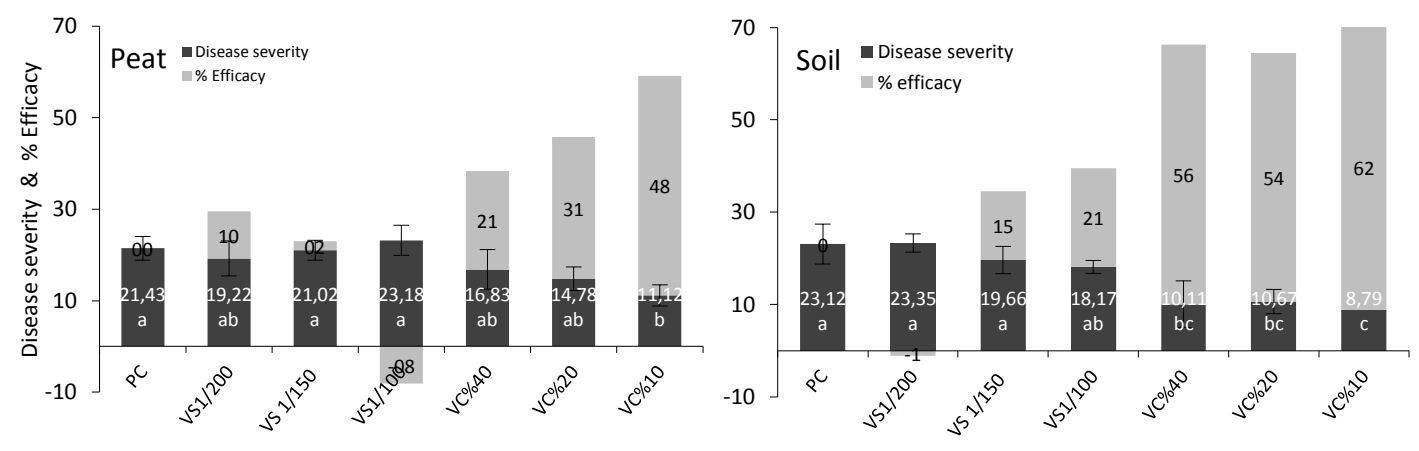

Figure 1. The effect of solid and liquid vermicompost applied to soil and peat growth mediums on Bacterial common blight disease caused by Xap. Disease severity was scoredon the basis of scale of 1-5 after 21 days in pathogen incoluation. The gray color indicates the \% efficacy and the black part of the column indicates the severity of the disease.

Şekil 1. Toprak ve torf yetiştirme ortamlarına uygulanan katı ve sıvı vermikompostun Xap'nin neden olduğu fasulye adi yaprak yanıklığı hastalığına etkisi. Hastalık şiddeti patojen uygulamasında 21 gün sonra 1-5 skalası ile değerlendirilmiş. Gri renki kolon \% etkinliği, siyah kolon ise hastalık şiddetini göstermektedir.

* Mean values followed by the same letter were not significantly different based on the Duncan's Multiple Range Test at $\mathrm{P}<0.05$ significance level. $\mathrm{N}:>15$. 
In soil growth medium, all doses of VC application significantly inhibited the disease. The most successful application was VC10\% with $62 \%$ efficacy, followed by VC $20 \%$ and VC40\% with 54 and $56 \%$ efficiencies. The obtained effects were also statistically significant. VS applications did not have a significant effect on disease formation in soil growth medium (Fig.1). In general, VC10\% was the most successful in suppressing disease, but no significant effect was observed for VS.

\section{Total Chlorophyll Content of the Leaves}

The total leaf chlorophyll content of bean seedlings varied according to vermicompost form and growth medium. The highest chlorophyll content was observed in VS 1/200 Xap application in peat and VS 1/150 Xap applicatin in soil. The VC 40\% application of had a negative effect on the total chlorophyll content in both growth media in presence/absence of the disease and caused a decrease. (Fig. 2).
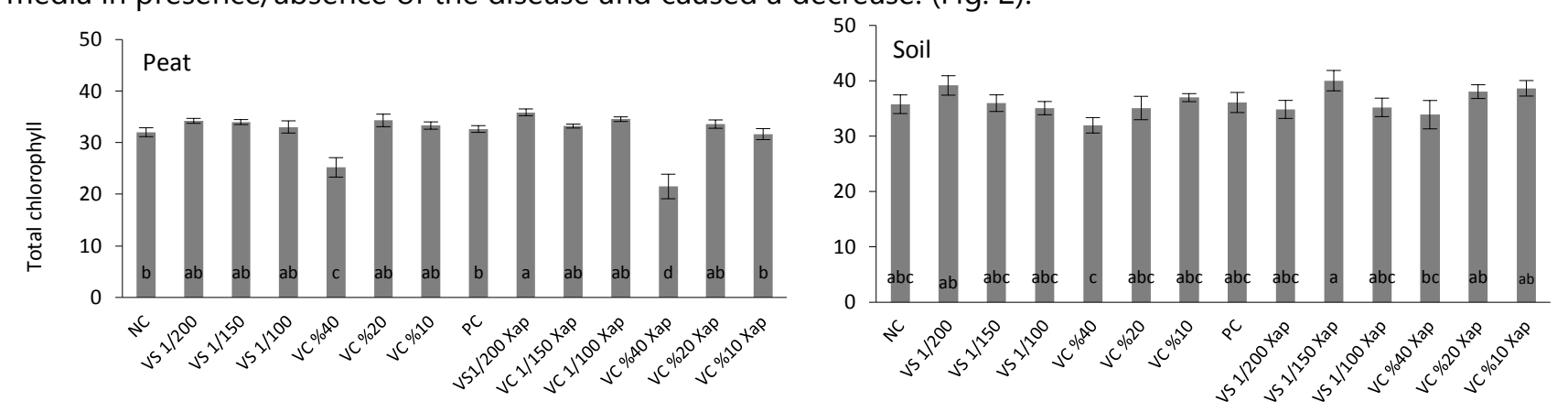

Figure 2. The effect of vermicompost forms (VC, VS) on total chlorophyll content in peat and soil growth media. Şekil 2. Vermikompost formlarının (VC, VS) torf ve toprak yetiştirme ortamlarında toplam klorofil içeriğine etkisi.

* Mean values followed by the same letter were not significantly different based on the Duncan's Multiple Range Test at $\mathrm{P}<0.05$ significance level. $\mathrm{N}:>12$

\section{Plant Growth Parameters}

\section{Root Fresh Weight (RFW)}

The lowest values were obtained from the control groups (NC, PC) in terms of plant root fresh weight in the peat growth medium and the highest values were obtained from VC $10 \%$ and $20 \%$ applications. Under the pressure of disease, the most successful VC application compared to the positive control was obtained from $20 \%$ Xap group. Although the other applications showed a positive effect, but they were not found to be significant (Fig. 3). In soil growth medium, the lowest value was taken from the VC $40 \%$ application and the highest root age weight VS was taken from the 1/100 group. VS $1 / 100$ Xap group was the most successful application under disease pressure. VC applications had no positive effect on root fresh weight. Furthermore, VS applications yielded better results in soil growing environment both under disease pressure and in disease-free groups compared to VC applications (Fig. 3).
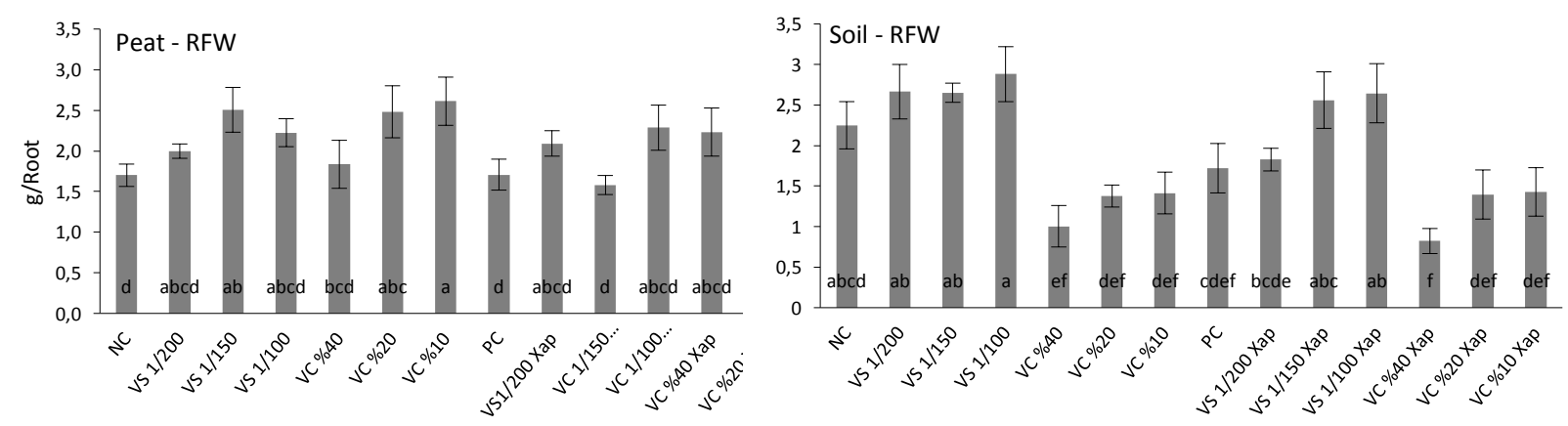

Figure 3. Plant Root fresh weight (RFW) of VC, VS applications in peat and soil growth media effect. şekil 3. VC ve VS uygulamalarının torf ve toprak yetiştirme ortamlarında bitki kök yaş ağırliğına (RFW) etkisi.

* Mean values followed by the same letter were not significantly different based on the Duncan's Multiple Range Test at $P<0.05$ significance level. $\mathrm{N}:>12$.

\section{Root Dry Weight (RDW)}

Root dry weight values varied according to growth medium. In peat medium, the lowest VC value was obtained from 10\% Xap group and the highest VC value was obtained from 10\% group. In general, however, there was no statistically significant difference between the groups in the presence/absence of pathogens (Fig. 4). In soil medium, the highest value was obtained from VS 1/100 group and the lowest value was obtained from VC 40\% 
Xap group in terms of RDW, but the difference between applications was not found to be statistically significant (Fig. 4). Under disease stress, the most successful group that achieved an increase in RDW compared to the positive control was VS 1/100 Xap. Other VS applications did not make a statistically significant difference. In addition, although VC applications under disease stress caused a decrease compared to the positive control, this effect was not found to be statistically significan.
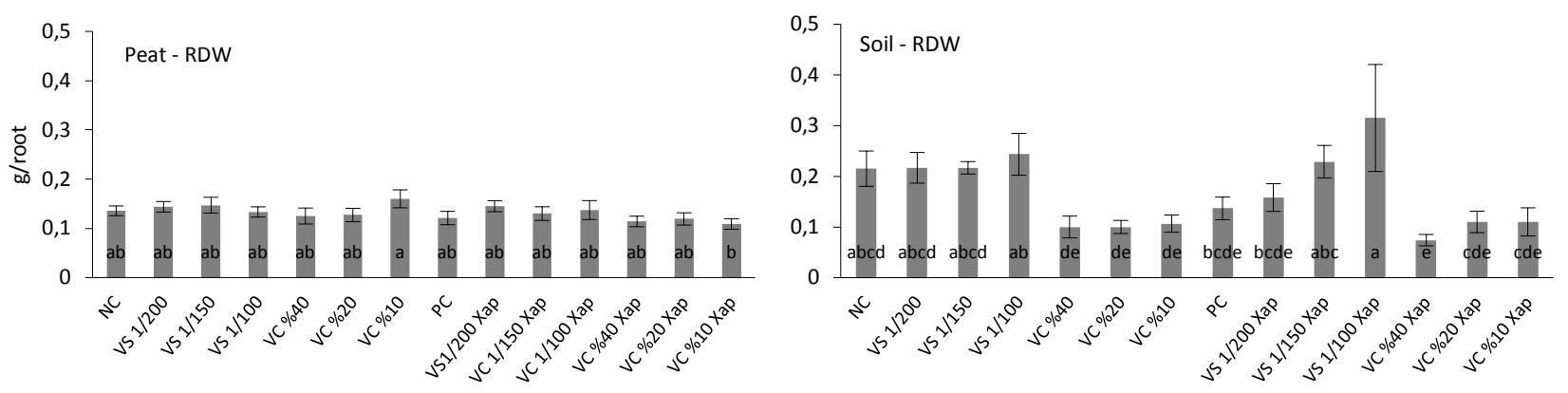

Figure 4. RDW effect of vermicompost formulation (VC, VS) on peat and soil growing medium.

Şekil 4. Vermikompost formulasyonunun (VC, VS) torf ve toprak yetiştirme ortamın da RDW etkisi.

*Mean values followed by the same letter were not significantly different based on the Duncan's Multiple Range Test at $\mathrm{P}<0.05$ significance level. $\mathrm{N}$ : $>12$.

\section{Shoot Fresh Weight (SFW)}

No significant effect of VC and VS applications on shoot fresh weight was observed in soil growth medium. However, in conditions where there is no disease pressure in peat medium, application VC $20 \%$ significantly increased shoot fresh weight and this positive effect was observed even under disease stress. Other applications showed no significant effect compared to their respective control groups (NC and PC) (Fig. 5).

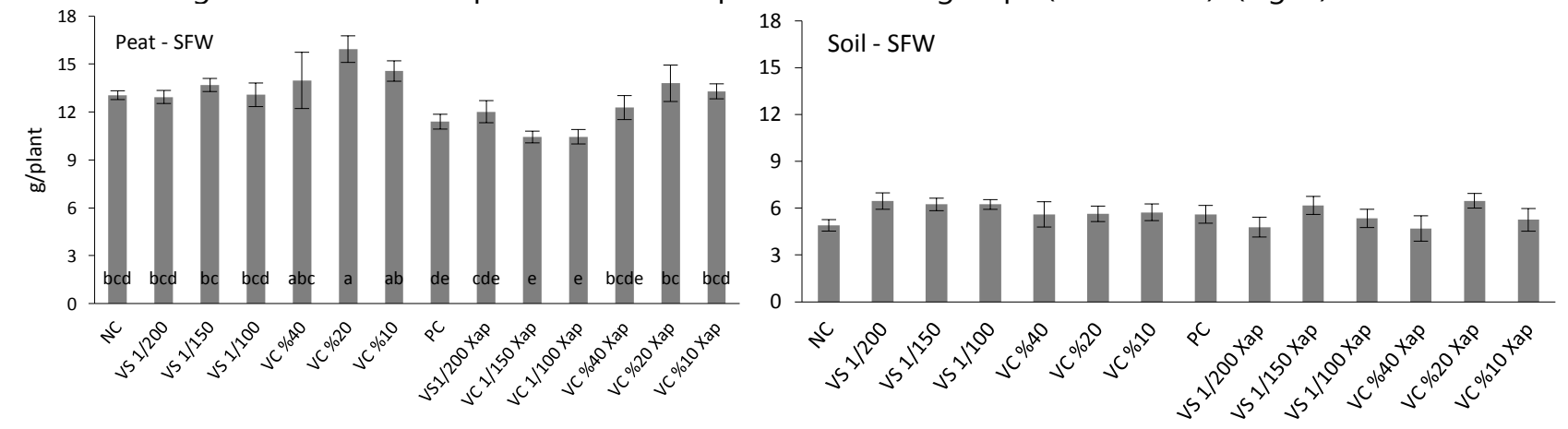

Figure 5. Effect of different vermicompost formulations (VC, VS) on shoot weights of common bean developed in different growth media (mixture of peat and soil).

Şekil 5. Farklı vermikompost formulasyonunun (VC, VS) farklı yetişstirme ortamlarında (torf ve toprak karışımı) geliştirilen fasulye sürgün yaş ağırlıklarına etkisi.

*Mean values followed by the same letter were not significantly different based on the Duncan's Multiple Range Test at $\mathrm{P}<0.05$ significance level. N: >12.

\section{Shoot Dry Weights (SDW)}

In peat growth medium, the highest values of SDW were obtained from NK and VS 1/150 applications while the lowest value was obtained from VC $40 \%$ application. Under the pressure of the disease, VC $40 \%$ Xap application significantly reduced the dry weight of the shoot compared to the positive control group. No statistically significant difference was observed in other applications, VS 1/200 application yielded the highest value in soil growth medium. While the lowest VC value yielded from the 40\% Xap application under the pressure of disease, no statistically significant difference was found between the groups (Fig. 6). 

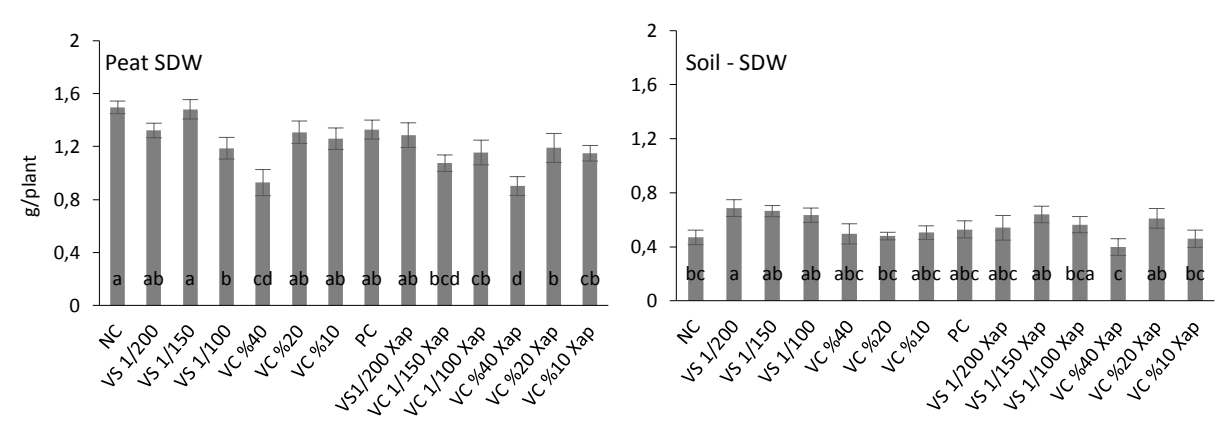

Figure 6. The effect of different vermicompost formulation (VC, VS) on peat and soil growth media in terms of SDW of bean. Şekil 6. Vermikompost formulasyonunun (VC, VS) torf ve toprak yetiştirme ortamlarına uygulamasının fasulye SDW etkisi. *Mean values followed by the same letter were not significantly different based on the Duncan's Multiple Range Test at $\mathrm{P}<0.05$ significance level. N: $>12$

\section{DISCUSSION}

In this study, the effect of solid and liquid vermicompost forms on common blight disease caused by Xap, and plant growth parameters were investigated in two different growing media consisting of soil mixture and peat.

Composting and vermicompost are the two best methods for biological conversion of solid organic wastes (Datta et al., 2016). However, nutritional quality and microbial activity of vermicompost is higher than compost (Tognetti et al., 2005). In addition, the mixing of solomic fluid in the digestive system of worms into the structure of vermicompost, separates vermicomposts from other composts. Enzymes and proteins such as fetidine, agglutidine, chitinase, lumbricidine which are present in the structure of solomic fluid enable the vermicompost to gain antimicrobial properties (Wang et al., 2006). This property makes important contributions to its effectiveness against soil pathogens.

Franke-Whittle et al. (2019) showed that the chemical and microbiological properties of vermicomposts may vary according to raw material, production process and region. In this framework, the differences in liquid and solid form of vermicompost can affect its effectiveness (Bademkıran et al., 2018). There is still a lack of information on liquid vermicompost production methodology and optimum application rates according to the target (SimsekErsahin, 2011). In contrast, while solid vermicompost can only be applied to soil, liquid vermicompost may be applied to leaves, seeds and soil (Scheuerell and Mahaffee, 2002). On the other hand, although solid form vermicompost applications are limited, slow release provides long-term efficacy.

In our study, it was determined that vermicompost in two different forms had different effects on chlorophyll content, plant development and disease severity. It was observed that in soil medium VS applications increased root development even under disease pressure. However, in peat medium, VC application was more successful. Also, in peat medium VC $20 \%$ applications were successful with regard to shoot fresh weight. Bademkıran et al. (2018) have revealed that liquid vermicompost gives better results than solid vermicompost in terms of morphological and developmental parameters in field conditions. In contrast, Zaller (2006) could not determine an effect of foliar application of aqueous vermicompost extracts on plant growth and nutrient content of different tomato varieties under field conditions. On the other hand, thorough vermicompost studies were found to show increase in fresh and dry weight of the chard (Aksu et al., 2017), bean (Kadam and Pathade, 2014) and lettuce (Adiloğlu et al., 2018) and to improve of yield and clorophyll content in lettuce (Kibar, 2018). In general, it is seen that vermicompost forms may exhibit different effects according to plant type, application method and target. The findings of this study support this case.

In contrast, Zaller (2006) could not determine an effect of foliar application of aqueous vermicompost extracts to different tomato varieties under field conditions, in terms of plant growth and nutrient content. On the other hand, thorough vermicompost studies were found to show increase in fresh and dry weight of the Chard (Aksu et al., 2017), Bean (Kadam and Pathade, 2014) and Lettuce (Adiloğlu et al., 2018) and improvement of yield and clorophyll content in for lettuce (Kibar, 2018). In general, it is seen that Vermicompost forms may exhibit different effects according to plant type, application method and target. The findings of this study support this case.

The doses of vermicompost were observed to be an important factor for the promoting effect. So that, one of the most significant results of our study is that the VC $40 \%$ application adversely affects plant growth and chlorophyll content in both growing medium (peat and soil). Atiyeh et al. (2000) observed the adverse effects of high application dose, in the form of a decrease in the number of flowers in tomatoes. Lazcano and Dominguez, (2010) observed that the application of $25 \%$ vermicompost in primrose and pansy caused death of $20 \%$ of plants, 
photosynthetic damage, decrease in leaf size and flower formation. In general, it appears that it is necessary to adjust the application doses according to the culture plant.

For maximum benefit, Franke-Whittle et al. (2019) stated that growing environment and plant factors should be taken into consideration rather than compost characteristics alone. In our study, it was observed that the effects of liquid and solid vermicompost applications on plant growth and disease varied according to soil and peat growth media. The addition of worms and vermicompost to soil may improve microbial diversity, physical properties of the soil and its nutrient content (Pathma and Sakthivel, 2012; Gupta et al., 2014; Datta et al., 2016). Also, it has been determined that vermicompost application provides more positive contributions to soil pore rate, useful water content, cation exchange rate in clay soil compared to sandy soil and increases bean yield and growth parameters (Manivannan et al., 2009).

It was observed that VC application significantly suppressed the common bean blight caused by Xap in both growth media. However, it was also observed that the dose of VC affects the suppression level. On the other hand, no suppressive effect of VS application was determined in both growing media. In the soil growth medium, all three doses of VC were suppressed the disease significantly. On the other hand, in the peat growth medium, it was observed that only $10 \%$ application of VC suppressed the disease significantly. The $10 \%$ application dose was the most successful application for both growing media. Although many studies have been conducted on the disease suppression properties of vermicompost applications on culture plants such as chili pepper, strawberry, radish, grape and cucumber; these studies are generally focused on soil based fungal pathogens such as Phytophthora spp., Fusarium spp., Pythium spp., Rhizoctonia spp., Verticillium spp. and Plectosporium spp. (Chaoui et al., 2002; Scheuerell and Mahaffee, 2002; Sarma et al., 2010; Simsek-Ersahin, 2011; Datta et al., 2016). In these studies, it was stated that the main factor in disease suppression was the change in soil microflora due to vermicompost. The change in soil microflora is argued to be based on the suppression of pathogens in the soil by mechanisms such as competition, antibiosis, hyperparasitism. In addition, it has been reported that, besides facilitating nutrient uptake, useful compost bound humic acid fractions and plant growth regulators (Sarma et al., 2010) which can limit disease development by supporting plant health.

It is possible that the factors mentioned in this study may be effective in decreasing the severity of the disease. However, the fact that Xap is a leaf pathogen, inoculated directly to the leaves in the study and that vermicompost is applied only to the soil shows that other mechanisms might be involved to protect of plant. In this context, the first mechanism which should be considered is the stimulated plant induced systemic resistance mechanisms. A limited number of studies have demonstrated that this mechanism may also be effective with compost applications. It was determined that compost application to Arabidopsis thaliana activated the GUS gene, which is an induced resistance marker, and that Pseudomonas syringae pv. maculicola was significantly suppressed (Zhang at al., 1998). Mishra et al. (2018) found that vermicompost extracts were upregulated the CHIT-1, PAL-1 and LOX-1 genes by activating plant induced resistance in the cucumber. The bacterial speck disease and its pathogen Pseudomonas syringae pv. tomato (Vallad et al., 2003), and tomato leaf spot disease caused by Septoria lycopersici (Kavroulakis et al., 2005) were limited with compost application the way of inducing systemic resistance mechanism. The findings obtained in our study show that stimulated plant resistance might in effect. In addition, the observed decrease in level of disease with the VC40\% application may be caused by the stress of the plant due to phytotoxicity or damage. As it is known, systemic acquired resistance (SAR) system, which is one of the basic resistance mechanisms of plants, may activate by damage, besides biotic and abiotic factors (Conrath, 2006).

Also, the decrease in disease severity might had be caused by endophytic microorganisms which may be present in the vermicompost microflora. Endophyte bacteria or microorganisms is live in the internal tissues of the plant but do not cause any disease or harm (Hardoim et al., 2008). In the pathosystem we created with vermicompost in the study, endophyte microorganisms may have entered the plant and cololonized all tissues of the plant through vascular bundles. Thus, the pathogen might had be suppressed within the plant via biological control mechanisms such as competition, antibiosis and hyperparasitism.

\section{CONCLUSION}

The vermicompost applications in liquid and solid forms are observed to affect plant growth parameters at different levels, according to the growth medium was determined that application doses were especially important in solid vermicompost and when it was added to the growth medium at a rate of $40 \%$ adversely affected plant growth parameters and caused phytotoxicity. When applied to the growth medium by irrigation, no effect of liquid vermocompost was observed to the leaf disease caused by Xap. In contrast, solid vermicompost was 
found to be successful in suppressing the disease in both growth media. This implies that one or more of the above-mentioned mechanisms may have limited the severity of the disease by working together.

The vermicompost application might help to plant growth and control the disease, thereby it can be reduced the chemical fertilizer and pesticide inputs. This shows that vermicompost applications may be ensured the control of the leaf pathogens with environmentally friendly and sustainable approach.

\section{CONFLICT OF INTEREST}

Authors have declared no conflict of interest.

\section{DECLARATION OF AUTHOR CONTRIBUTION}

Authors declares the contribution of the authors is equal.

\section{REFERENCES}

Adiloğlu, S., Açıkgöz, F. E., Solmaz, Y., Çaktü, E., \& Adiloğlu, A. (2018). Effect of vermicompost on the growth and yield of lettuce plant (Lactuca sativa L. var. crispa). International Journal of Plant \& Soil Science, 21, 1-5.

Akköprü, A. (2020). Potential using of transgenerational resistance against common bacterial blight in Phaseolus vulgaris. Crop Protection, 127. 104967.

Aksu, G., Köksal, S. B., \& Altay, H. (2017). Effects of vermicompost on some soil properties and yield of chard plant. COMU Journal of Agriculture Faculty, 5(2), 123-128.

Atiyeh, R. M., Arancon, N. Q., Edwards, C. A., \& Metzger, J. D. (2000). Influence of earthworm-proessed pig manure on the growth and yield of greenhouse tomatoes. Bioresour Technology, 75, 175-180.

Bademkıran, F., Çığ, A., \& Türkoğlu, N. (2018). The effects of dosages of solid and liquid earthworm fertilizers on plant growth of daffodil (Narcissus cv. 'Royal Connection'). Turkish Journal Of Agricultural and Natural Sciences, 5, 676-684.

Bellitürk, K., \& Görres, J. H. (2012). Balancing vermicomposting benefits with conservation of soil and ecosystems at risk of earhworm invasions. VIII. International Soil Science Congress on Land Degradataion and Challenges in Sustainable Soil Management, Çeşme-izmir.

Bruce, T. J. A. (2010). Tackling the threat to food security caused by crop pests in the new millennium. Food Security, 2, 133141.

CABI. (2019). Xanthomonas axonopodis pv. phaseoli (bean blight). Invasive Species Compendium. https://www.cabi.org/isc/datasheet/56962. Access date: 08 Ağustos 2020.

Chaoui, H., Edwards, C. A., Brickner, A., Lee, S. S., \& Arancon, N. Q. (2002). Suppression of the plant diseases, Pythium (dampingoff), Rhizoctonia (root rot) and Verticillium (wilt) by vermicomposts. International Conference of Pests \& Diseases, Brighton UK.

Conrath, U. (2006). Systemic acquired resistance. Plant Signaling \& Behavior, 1, 179-184.

Datta, S., Singh, J., Singh, S., \& Singh, J. (2016). Earthworms, pesticides and sustainable agriculture: a review. Environmental Science and Pollution Research, 23, 8227-8243.

Domínguez, J., \& Edwards, C. A. (2011). Vermiculture Technology: Earthworms, Organic Waste and Environmental Management: In: R. L. Sherman (Ed.), Relationships Between Composting and Vermicomposting: Relative Values of The Products, (pp.1-14) 2nd ed. Florida, USA. CRC Press.

Edwards, C. A., \& Arancon, N. Q. (2004). Interactions among organic matter earthworms and microorganisms in promoting plant growth. In C.A. Edwards (Editor in Chief), F. Magdoff, R. Weil (Eds.), Functions and Management of Organic Matter in Agro ecosystems. (pp. 327- 376), Florida, USA. CRC Press.

Edwards, C. A., Arancon, N. Q., \& Sherman, R. L. (2010). Vermiculture technology: earthworms, organic wastes, and environmental management. CRC Press. Florida, USA.

EPPO, (2006). Data sheets on quarantine pests Xanthomonas axonopodis pv. phaseoli. CABI and EPPO for the EU under Contract 90/399003. http://www.eppo.int/QUARANTINE/bacteria/Xanthomonas_phaseoli /XANTPH_ds.pdf. Access date: 09 Ağustos 2020. 
Öztürkci and Akköprü, Effects of Solid and Liquid Vermicompost Application on Bean Growth and Common Bacterial Blight Disease in Different Growth Medium

Franke-Whittle, I. H., Juárez, M. F. D., Insam, H., Schweizer, S., Naef, A., Topp, A. R., \& Manici, L. M. (2019). Performance evaluation of locally available composts to reduce replant disease in apple orchards of central Europe. Renewable Agriculture and Food Systems, 34, 543-557.

Graham, P. H., \& Ranalli, P. (1997). Common bean (Phaseolus vulgaris L.). Field Crops Research, 53, 131-146.

Griffin, K., Gambley, C., Brown. P., \& Li, Y. (2017). Copper-tolerance in Pseudomonas syringae pv. tomato and Xanthomonas spp. and the control of diseases associated with these pathogens in tomato and pepper; A systematic literature review. Crop Protection, 96, 144-150.

Gupta, S., Kushwah, T., \& Yadav, S. (2014). Role of earthworms in promoting sustainable agriculture in India. International Journal of Current Microbiology and Applied Sciences, 3, 449-460.

Hardoim, P. R., Van Overbeek, L. S., \& Van Elsas, J. D. (2008). Properties of bacterial endophytes and their roposed role in plant growth. Trends in Microbiology, 16, 463-471.

Kadam, D., \& Pathade, G. (2014). Effect of tendu (Diospyros melanoxylon RoxB.) leaf vermicompost on growth and yield of French bean (Phaseolus vulgaris L.). International Journal of Recycling of Organic Waste in Agriculture, 3(1), 44-51.

Kavroulakis, N., Ehaliotis, C., Ntougias, S., Zervakis, G. I., \& Papadopoulou, K. K. (2005). Local and systemic resistance against fungal pathogens of tomato plants elicited by a compost derived from agricultural residues. Physiological and Molecular Plant Pathology, 66, 163-174.

Kharayat, B. S., \& Singh, Y. (2016). Studies on interactions among bioagents colonized vermicompost, rhizospheric earthworms and stalk rot disease of sorghum caused by Erwinia chrysanthemi. AJAR, 1, 5.

Kibar, B. (2018). Determination of the interrelationships among plant properties, some quality properties and elements in lettuce. International Journal of Agriculture and Wildlife Science, 4, 149-160.

Lazcano, C., \& Dominguez, J. (2010). Effects of vermicompost as a potting amendment of two commercially-grown ornamental plant species. Spanish Journal of Agricultural Research, 8, 1260-1270.

Manivannan, S., Balamurugan, M. M., Parthasarathi, K., Gunasekeran, G., \& Ranganathan, L. S. (2009). Effect of vermicompost on soil fertility and crop productivity-beans (Phaseolus vulgaris). Journal of Environmental Biology, 30, $275-281$.

Mishra, S., Wang, K. H., Sipes, B. S., \& Tian, M. (2018). Induction of host-plant resistance in cucumber by vermicompost tea against root-knot nematode. Nematropica, 48, 164-171.

Pathma, J., \& Sakthivel, N. (2012). Microbial diversity of vermicompost bacteria that exhibit useful agricultural traits and waste management potential. SpringerPlus, 1, 1-26.

Saday, C. (2013). To give experience about vermiculture production, legal difficulties and solutions and production processes and development. TEMA Foundation National Vermiculture Workshop. İstanbul, Turkey

Sahni, S., Sarma, B. K., Singh, D. P., Singh, H. B., \& Singh, K. P. (2008). Vermicompost enhances performance of plant growthpromoting rhizobacteria in Cicer arietinum rhizosphere against Sclerotium rolfsii. Crop Protection, 27, 369-376.

Sarma, B. K., Singh, P., Pandey, S. K., \& Singh, H. B. (2010). Vermicompost as modulator of plant growth and disease suppression. Dynamic Soil, Dynamic Plant, 4, 58-66.

Scheuerell, S., \& Mahaffee, W. (2002). Compost tea: Principles amd prospects for plant disease control. Compost Science and Utilization, 10, 313-338.

Simsek-Ersahin, Y. (2011). The use of vermicompost products to control plant diseases and pests. In A. Karaca (Ed.) Biology of Earthworms (pp. 191-213). Springer, Berlin, Heidelberg.

Singh, S. P., \& Schwartz, H. F. (2010). Breeding common bean for resistance to diseases: a review. Crop Science, 50, $2199-2223$.

Singh, S. P., Miklas, P. N. (2015). Breeding common bean for resistance to common blight: A review. Crop Science, 55, $971-984$.

Singh, R., Jagtap, G. P., Bannihatti, R. K., Jatwa, T. K., Khan, I., \& Meena, N. K. (2017). Evaluation of organic amendments against ralstonia solanacearum causing bacterial wilt in ginger. International Journal of Bio-resource and Stress Management, 8 , 556-560.

Tognetti, F. L., Mazzarino, M. J., \& Hernández, M. T. (2005). Composting vs. vermicomposting: a comparison of end product quality. Compost Science \& Utilization, 13, 6-13.

Tutar, U. (2013). Investigation of antimicrobial activity on some plant pathogens of obtained from the earthworm's vermicompost. Cumhuriyet Science Journal, 34, 1-12. 
Öztürkci and Akköprü, Effects of Solid and Liquid Vermicompost Application on Bean Growth and Common Bacterial Blight Disease in Different Growth Medium

Vallad, G. E., Cooperband, L., \& Goodman, R. M. (2003). Plant foliar disease suppression mediated by composted forms of paper mill residuals exhibits molecular features of induced resistance. Physiological and Molecular Plant Pathology, 63, 6577.

Vanlı, H., \& Bedük, S. (2013). Sustainable trade; climate change and production of organic fertilizer with vermiculture system. II. Rize Development Symposium, Rize, Turkey.

Vidaver, A. K. (2002). Uses of antimicrobials in plant agriculture. Clinical Infectious Diseases, 34, 107-110.

Wang, C., Sun, Z. J., \& Zheng D. (2006). Research advance in antibacterial immunity ecology of earthworm. The Journal of Applied Ecology, 17(3), 525-529.

Zaller, J. G. (2006). Foliar spraying of vermicornpost extracts: effects on fruit quality and indications of late-blight suppression of field-grown tomatoes. Biological Agriculture \& Horticulture, 24, 165-180.

Zhang, W., Han, D. Y., Dick, W. A., Davis, K. R., \& Hoitink. H. A. J. (1998). Compost and compost water extract-induced systemic acquired resistance in cucumber and Arabidopsis. Phytopathology, 88, 450-455. 